\title{
Repetition of estrus is the most frequent reproductive problem after breeding in dairy cattle from Rio de Janeiro, Brazil
}

\author{
Eduardo Kenji Nunes Arashiro ${ }^{1}$ Hugo Libonati ${ }^{2}$ Gustavo Bervian dos Santos ${ }^{1}$ \\ Luiz Altamiro Garcia Nogueira ${ }^{1}$ Guilherme Nunes de Souza ${ }^{3}$ Walter Lilenbaum ${ }^{2}$ \\ Felipe Zandonadi Brandão ${ }^{1^{*}}$
}

\author{
${ }^{1}$ Faculdade de Veterinária, Universidade Federal Fluminense (UFF), 24230-340, Niterói, RJ, Brasil. E-mail: fzbrandao@id.uff.br. \\ "Corresponding author. \\ ${ }^{2}$ Laboratório de Bacteriologia Veterinária, Universidade Federal Fluminense (UFF), Niterói, RJ, Brasil. \\ ${ }^{3}$ Embrapa Gado de leite, Juiz de Fora, MG, Brasil.
}

\begin{abstract}
Reproductive efficiency is one of the key elements for any milk production system to be successful. In this regard, reproductive management must be planned properly and the identification of the main reproductive disorders that affect the herd is primordial for decisionmaking. The aim of the present study was to identify the main reproductive problems that affect dairy herds on Rio de Janeiro (RJ), Brazil. Data regarding breed, age, reproductive disorder occurrence, and breeding system were individually collected from dairy cows raised at 25 farms located at RJ. The occurrence of reproductive disorders was reported in 37\% of the studied animals. Estrous repetition (76.2\%) and abortion (15.6\%) were the most frequent reproductive problems reported. Estrous repetition was more common in older animals (>6 years old). However, an association between abortion and age of animal was not observed, nor an association between breeding system and occurrence of abortion. The present results demonstrated that estrous repetition is the main obstacle to the reproductive efficiency in dairy herds at RJ, and that the replace of older cows by heifers is an important point within reproductive management of a dairy herd. Key words: dairy cattle, reproductive disorders, repeat breeding.
\end{abstract}

Repetição de estro é o problema reprodutiva mais comum em vacas leiteiras do Estado do Rio de Janeiro, Brasil

\begin{abstract}
RESUMO: A eficiência reprodutiva é um dos principais elementos para qualquer sistema de produção de leite ser bem-sucedida. Neste contexto, o manejo reprodutivo deve ser planejado adequadamente e a identificação das principais desordens reprodutivas que afetam o rebanho é essencial para a tomada de decisão. O objetivo do presente estudo foi identificar os principais problemas reprodutivos que acometem rebanhos leiteiros no Rio de Janeiro (RJ), Brasil. Dados relacionados com a raça, idade, ocorrência de problema reprodutivo e o sistema de acasalamento foram individualmente coletados de vacas leiteiras criadas em 25 fazendas localizadas no RJ. A ocorrência de desordens reprodutivas foi relatada em $37 \%$ dos animais estudados. A repetição de estro (76,2\%) e abortamento (15,6\%) foram os problemas reprodutivos mais frequentemente relatados. A repetição de estro foi mais comum em animais mais velhos (>6 anos). Contudo, uma associação entre abortamento e idade do animal não foi observada, nem uma associação entre o sistema de acasalamento e a ocorrência abortamento. Os presentes resultados demonstraram que a repetição de estro é o principal obstáculo para a eficiência reprodutiva nos rebanhos leiteiros do RJ, e que a substituição de animais mais velhos por novilhas é um importante ponto dentro do manejo reprodutivo de um rebanho leiteiro. Palavras-chave: gado de leite, problemas reprodutivos, repetição de cio.
\end{abstract}

An adequate reproductive performance is essential for the success of any animal production system. In dairy cattle farms, studies from Brazil and USA demonstrated that milk and calves sale is responsible for the vast majority of cash receipt (BUSS \& DUARTE, 2010; LOPES et al., 2011; RIBEIRO et al., 2012). High reproductive indexes means high birth rate, which in turn leads to more lactating animals and shorter calving intervals, consequently increasing milk yield and number of calves per year (reviewed by CHEBEL \& RIBEIRO, 2016). Thus, it is clear that a good reproductive efficiency is imperative for economic viability of dairy farms.

In this context, reproductive management becomes a key element within dairy farms (GIORDANO et al., 2011), and identification of the main reproductive disorders that affect the herd is primordial for decision-making. The aim of the present study was to identify the main reproductive 
problems after breeding that affect dairy herds on Rio de Janeiro (RJ), Brazil.

The study was conducted on dairy cattle herds from three regions of RJ (North-northwest, South and Central region). According to the practitioner veterinarian responsible for the herds, the herds that had reported reproductive disorders in the last reproductive season (2015) were selected, totaling 25 herds (10 from North-northwest, 10 from South, and 5 from Central region). The number of cows in the herds ranged from 22 to 235 . In each farm, 20 adult animals were randomly selected (totaling 500 cows) and data regarding breed, age, reproductive problems occurrence, and breeding system were individually collected. Within reproductive problems, animals with estrous repetition was those in which a single return to estrus signs was observed approximately 20 days after breeding. Association between reproductive problems with age and breeding system was determined by Qui-square test and logistic regression model was used to estimate the risk of reproductive problems. A probability of $\mathrm{P}<0.05$ was considered on both Qui-square test and logistic regression model, as well as explanatory variables within logistic regression model.

Breed composition of animals was as follows: Holstein-Zebu crossbred ( $\mathrm{n}=383,76.6 \%$ ), Gir $(n=75,15 \%)$, Jersey $(n=23,4.6 \%)$, Holstein $(\mathrm{n}=8,1.6 \%)$, and Jersey-Holstein crossbred $(\mathrm{n}=11$, $2.2 \%$ ). Regarding the age of animals, $24.4 \%$ of them were between 1-3 years old, $43.7 \%$ were between 4-6 years old, and 31.9\% were older than 6 years. Reproductive disorders were observed in $37 \%$ $(185 / 500)$ of animals, and the type of reproductive problem and percentage of animals affected by each one are shown in figure 1. Concerning the breeding systems, $41.8 \%$ of animals were bred using natural breeding combined with fixed-time artificial insemination, $35.4 \%$ using artificial insemination, $13.6 \%$ using natural breeding, $0.4 \%$ using embryo transfer, and in $8.8 \%$ more than one technique was used.

An interesting effect of age on the occurrence of reproductive problems was observed. Taking together, reproductive problems were more frequent $(\mathrm{P}<0.02)$ in animals older than 6 years $(47.6 \%)$ when compared to animals with $1-3$ or 4-6 years old (30.6\% and 33.8\%, respectively). Separately, an effect of age on estrous repetition was observed $(\mathrm{P}<0.001)$, since that problems was more common (odds ratio: 1.84 ; $95 \% \mathrm{CI}$ : 1.04 to 3.25 ) in animals older than 6 years $(42.3 \%)$ when compared to animals with 1-3 years old (27.9\%). Similarly, estrous repetition was more common $(\mathrm{P}<0.01)$ in animals submitted to natural breeding combined with FTAI (odds ratio: 2.37; 95\% CI: 1.19 to 4.71 ) when compared to animals submitted to natural breeding alone (39.9\% vs. $23.0 \%$, respectively). An association between abortion and age of the animal were not observed, nor an association between breeding system and occurrence of abortion.

Reproductive problems were identified in more than one third of the studied animals (37\%). Those results demonstrated that reproductive management in dairy farms at RJ remains a bottleneck for profitability of local dairy industry. A poor reproductive management strategy delays pregnancy establishment and consequently increases calving-to-conception interval, decreasing cash receipt due to lower milk and calves production (reviewed by GRÖHN \& RAJALA-SCHULTZ, 2000). Moreover, economic losses are also caused by involuntary culling of animals and greater expenses with veterinary services (BRITT, 1985).

The most important outcome of the study was that estrous repetition after breeding was by far the most frequent reproductive problem reported in herds (Figure 1). A survey performed in large US commercial farms reported that up to 9 inseminations were done before the decision to cull off the animal (CARAVIELLO et al., 2006). Due to its multifactorial nature, estrous repetition has a great negative impact on reproductive efficiency. After breeding, whether natural or artificial, estrous repetition indicated that conception failed to occur or, if it has occurred, the cow experienced pregnancy loss. Conception failure and early pregnancy disruption are multicausal disorders originated by infectious, environmental, nutritional, or management factors (VANROOSE et al., 2000; WILTBANK et al., 2016). Our outcomes demonstrated that estrous repetition was more frequent in older animals ( $>6$ years old). It has been reported that early embryo mortality is more common than conception failure, and that one of the factors associated to early embryo mortality is the age of the animal (reviewed by SARTORI \& DODE, 2008). A comprehensive review highlighted that lower follicular activity, lower oocyte quality, and poor uterine environment are more frequently observed in older animals, what may impair embryo development (VANROOSE et al., 2000). It was demonstrated that conception rate in heifers older than 26 months of age was $13 \%$ lower when compared to heifers at 15 16 months of age, presumably due to lower embryo survival rate (KUHN et al., 2006). This finding demonstrated that the replace of older cows by 


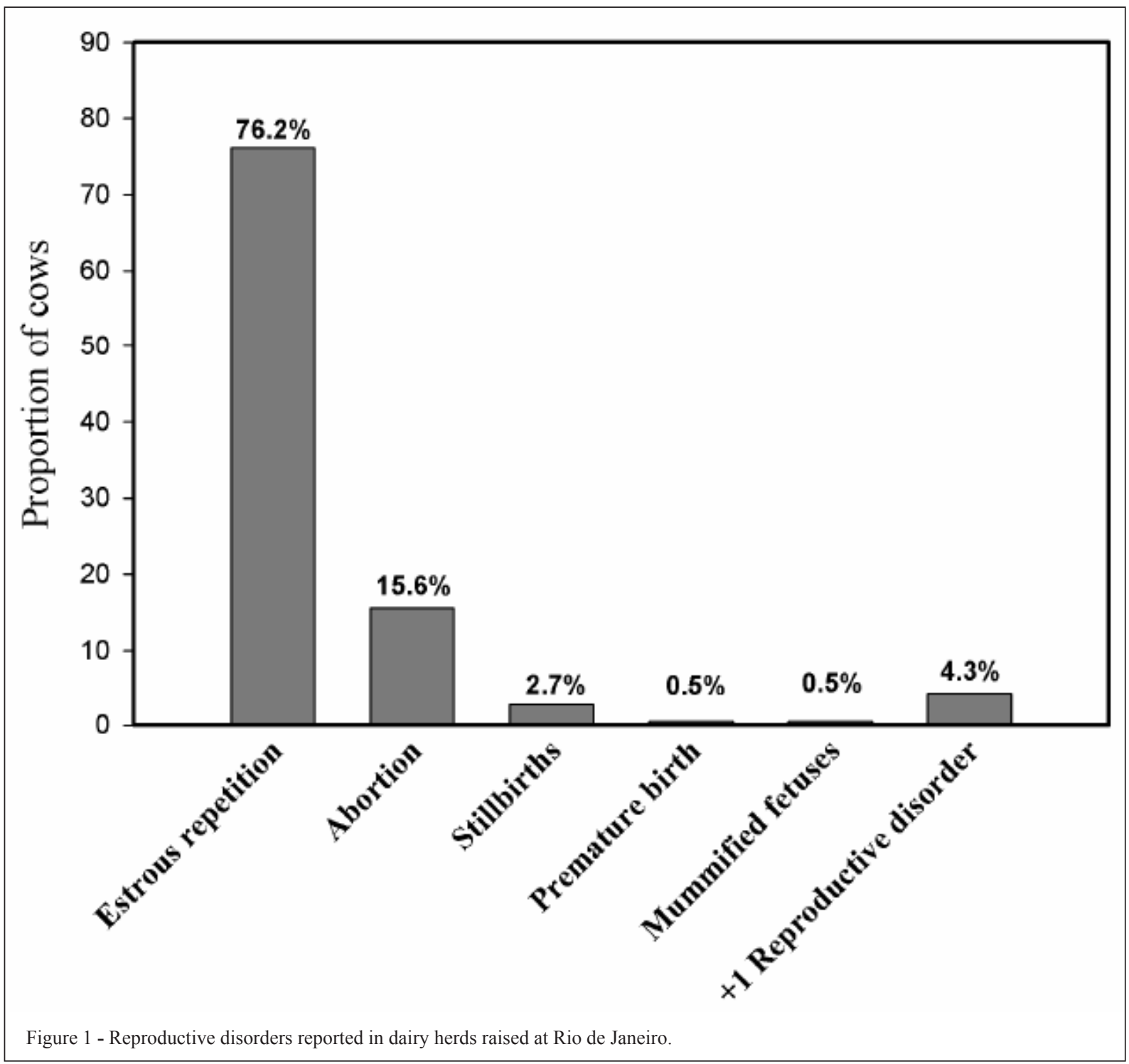

younger cows or heifers is an important point within reproductive management of a dairy herd.

Since the occurrence of stillbirths, premature births, and mummified fetuses were also reported, infectious pathogens as major causal agents cannot be ruled out. In this study, naturally mated animals did not present higher incidence of abortion than artificially inseminated animals. Despite of a serological study for reproductive diseases was not yet performed, in face of this result it is plausible to infer that occurrence of these reproductive problems is unlikely to be caused by sexually-transmitted infectious agents, even though the presence of infection by such pathogens (e.g. Campylobacter fetus or Tritrichomonas foetus) was previously described in bovines in RJ and other Brazilian States (ROCHA et al., 2009). Since sexually-transmitted agents are unlikely to be associated with the estrous repetitions or abortions observed in this study, the occurrence of others diseases that are not dependent on natural breeding, such as leptospirosis and brucellosis, should be further investigated. Despite all the efforts to control and eradicate these diseases, their prevalence remains both a national and local problem (LILENBAUM \& SOUZA, 2003; MOTA et al., 2016).

In conclusion, estrous repetition is the main obstacle to the reproductive efficiency in dairy herds at RJ. This problem was more common when FTAI associated with natural breeding was used as breeding 
system. A clear association with age of the animals was also observed. This finding demonstrated that the replace of older cows by heifers is an important point within reproductive management of a dairy herd.

\section{ACKNOWLEDGEMENTS}

The authors thank Brazilian research support institutes: Fundação de Amparo à Pesquisa do Estado do Rio de Janeiro (FAPERJ) for financial support to the study and for providing scholarship to EKNA, FZB, and WL; Coordenação de Aperfeiçoamento de Pessoal de Nível Superior (CAPES) for providing scholarship to GBS and HL; and Conselho Nacional de Desenvolvimento Científico e Tecnológico $(\mathrm{CNPq})$ for providing scholarship to FZB and WL. The authors also thank the veterinarians members of Rio Genetics Program (Marcello Ribeiro, José Carlos Junior, Sebastião Poubel, Márcio, Antônio Roberto, Pedro Afonso Alves, Isis Goulart, Guilherme Dutra, and José Gabriel de Almeida), for technical support in data collection. The authors are thankful to Dr. Eduardo Cavalcante for his help on technical visits.

\section{BIOETHICS AND BIOSSECURITY COMMITTEE APPROVAL}

The study was approved by Ethical Committee for Animal Use of Universidade Federal Fluminense (UFF) (CEUA \#713).

\section{REFERENCES}

BRITT, J.H. Enhanced reproduction and its economics implications. Journal of Dairy Science, v.68, n.6, p.1585-1592, 1985. Available from: <http://dx.doi.org 10.3168/jds.S0022-0302(85)80997-8>. Accessed: Nov. 04, 2016. doi: 10.3168/jds.S0022-0302(85)80997-8.

BUSS, A.E.; DUARTE, V.N. Study of economic viability of milk production in a farm located at Mato Grosso do Sul. [Estudo da viabilidade econômica da produção leiteira numa fazenda no Mato Grosso do Sul]. Custo e Agronegócio, v.6, n.2, p.110-130, 2010. Available from: <http:/www.custoseagronegocioonline.com.br/ numero2v6/producao\%20leiteira.pdf>. Accessed: Nov. 04, 2016.

CARAVIELLO, D.Z. et al. Survey of management practices on reproductive performance of dairy cattle on large US commercial farms. Journal of Dairy Science, v.89, p.4723-4735, 2006. Available from: <http://dx.doi.org/10.3168/jds.S00220302(06)72522-X>. Accessed: Jan. 25, 2017. doi: 10.3168/jds. S0022-0302(06)72522-X.

CHEBEL, C.R.; RIBEIRO, E.S. Reproductive systems for North America dairy cattle herds. Veterinary Clinics of North America: Food animal practice, v.32, n.2, p.267-284, 2016. Available from: $<$ http://dx.doi.org/10.1016/j.cvfa.2016.01.002>. Accessed: Nov. 05, 2016. doi: 10.1016/j.cvfa.2016.01.002.

GIORDANO, J.O. et al. An economic decision-making support system for selection of reproductive management programs on dairy farms. Journal of Dairy Science, v.94, p.6216-6232, 2011. Available from: <http://dx.doi.org/10.3168/jds.2011-4376>. Accessed: Nov. 05, 2016. doi: 10.3168/jds.2011-4376.
GRÖHN, Y.T.; RAJALA-SCHULTZ, P.J. Epidemiology of reproductive performance in dairy cows. Animal Reproduction Science, v.60-61, p.604-614, 2000. Available from: $<$ http://dx.doi. org/10.1016/S0378-4320(00)00085-3>. Accessed: Nov. 04, 2016. doi: $10.1016 / \mathrm{S} 0378-4320(00) 00085-3$.

KUHN, M.T. et al. Characterization of Holstein heifer fertility in the United States. Journal of Dairy Science, v.89, p.4907-4920, 2006. Available from: <http://dx.doi.org/10.3168/jds.S00220302(06)72541-3>. Accessed: Nov. 04, 2016. doi: 10.3168/jds. S0022-0302(06)72541-3.

LILENBAUM, W.; SOUZA, G.N. Factors associated with bovine leptospirosis in Rio de Janeiro, Brazil. Research in Veterinary Science, v.75, p.249-251, 2003. Available from: <http://dx.doi. org/10.1016/S0034-5288(03)00114-0>. Accessed: Nov. 05, 2016. doi: 10.1016/S0034-5288(03)00114-0.

LOPES, M.A. et al. Profitability study of milk production systems in Nazareno city (MG), Brazil. Ciência Animal Brasileira, v.12, n.1, p.58-69, 2011. Available from: <http://dx.doi.org/10.5216/cab. v12i1.7725>. Accessed: Nov. 03, 2016. doi: 10.5216/cab.v12i1.7725.

MOTA, A.L.A.A. et al. Large-scale study of herd-level risk factors for bovine brucellosis in Brazil. Acta Tropica, v.164, p.226-232, 2016. Available from: <http://dx.doi.org/10.1016/j. actatropica.2016.09.016>. Accessed: Nov. 05, 2016. doi: 10.1016/j. actatropica.2016.09.016.

RIBEIRO, E.S. et al. Economic aspects of applying reproductive technologies to dairy herds. Animal Reproduction, v.9, n.3, p.370-387, 2012. Available from: <http://www.cbra.org.br/pages/ publicacoes/animalreproduction/issues/download/v9n3/pag370387\%20(AR528).pdf>. Accessed: Nov. 10, 2016.

ROCHA, F.S. et al. Campylobacter fetus and Tritrichomonas foetus investigation in preputial mucous of bulls from Médio Paraíba/RJ region, Brazil. Ciência Rural, v.39, n.5, p.15871590, 2009. Available from: <http://dx.doi.org/10.1590/S010384782009005000103>. Accessed: Nov. 04, 2016. doi: 10.1590/ S0103-84782009005000103.

SARTORI, R.; DODE, M.A. Embryo mortality in AI, ET, IFV, and cloning [Mortalidade embrionária na IA, TE, FIV e clonagem]. In: SIMPÓSIO INTERNACIONAL DE REPRODUÇÃO APLICADA, 3., 2008, Londrina, PR. Anais do $3^{\circ}$ SIMPÓSIO INTERNACIONAL DE REPRODUCÃO APLICADA. São Paulo: Faculdade de Medicina Veterinária e Zootecnia, Universidade de São Paulo, 2008. 205 p. p.175-194. Accessed: Nov. 05, 2016. Available from: <http://www.siraa.com.br/edicoes/3osimposio-internacional-de-reproducao-animal-aplicada $>$.

VANROOSE, G. et al. Embryonic mortality and embryo-pathogen interactions. Animal Reproduction Science, v.60-61, p.131143, 2000. Available from: <http://dx.doi.org/10.1016/S03784320(00)00098-1>. Accessed: Nov. 05, 2016. doi: 10.1016/S03784320(00)00098-1.

WILTBANK, M.C. et al. Pivotal periods for pregnancy loss during the first trimester of gestation in lactating dairy cows. Theriogenology, v.86, p.239-253, 2016. Available from: <http:// dx.doi.org/10.1016/j.theriogenology.2016.04.037>. Accessed: Nov. 04, 2016. doi: 10.1016/j.theriogenology.2016.04.037. 